\title{
A REPARAÇÃO DO DANO MORAL
}

\author{
Antonio Carlos de Campos Pedroso \\ Professor Associado do Departamento de Filosofia e Teoria Geral do Direito \\ da Faculdade de Direito da USP
}

\begin{abstract}
Resumo:
O dano moral é uma lesão aos valores da pessoa humana. Atinge os componentes de sua personalidade e de seu prestígio social. Assim sendo, a reparação desse ilícito decorre de preceitos do jus naturae. O presente estudo pretende demonstrar que o nosso sistema legal não deve cuidar apenas da proteção dos valores econômicos, mas, resguardar, acima de tudo, o patrimônio moral. $\mathrm{O}$ dano moral deve ser objeto de ampla reparação mediante a previsão de pena privada e satisfação compensatória, aplicadas com eqüidade.
\end{abstract}

\begin{abstract}
:
The moral damage is a harm to the values of the human being. It affects one's personality and social prestige. Therefore, the reparation of such illicit derives from the principles of the jus naturae (Natural Law). This current essay intends to demonstrate that our legal system should care not only about the protection of the economic values, but also the defense of the moral wealth. The moral damage must be fully remedied by prevision of private seclusion and compensatory satisfaction, both applied with equity.
\end{abstract}

Sumário:

1. Introdução. O problema da reparação do dano moral.

2. Conceito de dano moral. Delimitação. Dano moral, dano patrimonial, reflexos patrimoniais do dano moral.

3. Fundamento da reparação: auto-realização da pessoa humana.

4. Principais objeções doutrinárias à teoria da reparação.

5.O princípio da reparação no Direito Comparado.

6. Análise normativa do preceito: as transgressões, as sanções, os obrigados e os pretensores.

7. Tipologia das transgressões.

8. A eqüidade na mensuração da sanctio juris. 
1. Introdução. O problema da reparação do dano moral.

Não contém o Código Civil brasileiro um princípio expresso relativo à reparação do dano moral. Tal situação tem suscitado interessante debate sobre a admissibilidade desse direito em face do nosso sistema legal.

Alguns juristas se pronunciaram pela tese do ressarcimento, argumentando que a sistemática do Código dá margem a essa possibilidade. Dentre eles podem ser destacados, pela importância das considerações expendidas, Clóvis Beviláqua e Pedro Lessa, o primeiro apresentando argumentos de ordem doutrinária e o segundo, traduzindo na jurisprudência, uma linha de orientação prudente e equitativa, para a análise do caso concreto. Com efeito, Clóvis, ao comentar o art. 76 do Código Civil, assevera que se o interesse moral justifica ação para defendê-lo, é inquestionável que o mesmo deve ser objeto de indenização.' Nosso Código admite que interesses morais venham a fundamentar ações judiciais. Por sua vez, Pedro Lessa, em memorável julgado, acolheu a tese, inaugurando nova linha jurisprudencial. ${ }^{2}$ Ponderou o magistrado que a impossibilidade de integral compensação do dano moral não impede sua reparação parcial, através de uma indenização que represente uma sanção de caráter aproximativo, isto é, nos limites das possibilidades humanas. Assim, Clóvis Beviláqua, buscando o sentido e o alcance da lei e Pedro Lessa, realizando aplicação prudencial do sistema normativo, já chamavam nossa atenção para a correta interpretação do sistema legal que não podia alcançar, apenas, a ofensa a interesses puramente patrimoniais.

Entretanto, outros juristas reconhecem existir, no sistema normativo, lacuna, isto é, falta de previsão do que deveria ser previsto para evitar o comprometimento da harmonia do ordenamento. No entendimento de Orlando Gomes, o nosso Código é omisso, não apresentando resultado satisfatório à pesquisa hermenêutica que visa encontrar o princípio capaz de englobar toda a casuística. ${ }^{3}$ Logo, só possibilita reparação em casos expressos nas normas particulares.

Ao contrário do que ocorre com o Código Civil brasileiro, legislações há em que o princípio da reparação do dano moral vem expressamente consagrado. Como exemplo, pode ser citado o Código suíço. De acordo com o art. 28, I, desse

1. Clóvis Beviláqua, Comentários ao Código Civil, $4^{\mathrm{a}}$ ed., v. 1, p. 313.

2. Pedro Lessa, Rev. Forense, v. XXIV, p. 475.

3. Orlando Gomes, Direito das Obrigações, I ed., p. 366, 1961. 
estatuto e 49 do Código das Obrigações, o ressarcimento, a título de reparação moral, é devido a quem for lesado nas suas "relações de interesses pessoais" por ato revestido de culpabilidade por parte do infrator. A obrigação alcança os danos imateriais. O sistema suíço que se vale de "claúsulas gerais", deixou a cargo da jurisprudência decidir a respeito dos casos a serem inseridos no contexto do princípio. Mas este é amplamente acolhido. ${ }^{4}$

A diversidade de orientação provém do debate doutrinário que a questão tem provocado, sendo uns defensores da reparação, como Alfredo Minozzi e Hans Albrecht Fischer, e outros, opositores, como Gabba e Chironi. ${ }^{5}$ Por sua vez, os que aceitam o ressarcimento, divergem sobre a aplicabilidade do princípio, sustentando o primeiro grupo, que ele deve ser considerado em toda a sua extensão, como hábil a envolver todas as hipóteses de danos morais, e reconvindo o segundo grupo, que referido princípio deve abranger, tão-somente, os casos de danos morais taxativamente previstos. Seria inadequada, nesta hipótese, a previsão pela técnica dos standards, isto é, diretrizes mais ou menos precisas, cuja apreciação ficaria a cargo dos magistrados, como é a situação já citada do Código Civil suíço.

O tema suscita interessante pesquisa, ou seja, a de se saber como os diferentes sistemas jurídicos vêm disciplinando a reparação do dano moral. Suscita, ainda, a análise de sua inegável vinculação aos princípios do Direito Natural, os quais reclamam reconhecimento da responsabilidade dos que atentam aos valores da pessoa humana. Com efeito, estes provêm da própria natureza humana e se irradiam no campo do Direito Positivo. A proteção dos direitos fundamentais da pessoa humana é imprescindível. ${ }^{6}$

Nosso trabalho tem por objetivo a apreciação do conceito, do fundamento e da sistemática do nosso sistema normativo. Abrangerá ainda o estudo da tipologia das transgressões e a cominação das respectivas sanções. $O$ estudo procura também analisar o princípio da reparação à luz do Direito Comparado, na medida em que esta pesquisa, confrontando as soluções dos diferentes sistemas contribui para eventual melhoria do nosso. Por fim, não deixa de se referir aos parâmetros de mensuração das medidas compensatórias.

4. Konrad Zweigert e Hein Kotaz, Introduzione al Diritto Comparato, Principi Fondamentali, Giuffrè, Milão, p. 213, 1992.

5. Alfredo Minozzi, Studio sul danno non patrimoniale, Società Editrice Libraria, p. 54 e ss., 1917.

6. Heinrich A. Rommen, Le Droit Naturel. Histoire-Doctrine, Egloff, Paris, 945, p.263-7; Helmut Coing, Fundamentos de Filosofia del Derecho, trad. Juan Manuel Mauri, Ariel, p.180 e ss., 1976. 
2. Conceito de dano moral. Delimitação. Dano moral, dano patrimonial, reflexos patrimoniais do dano moral.

A matéria desta pesquisa exige que algumas noções sejam relembradas. Preliminarmente, cumpre saber o que se entende por dano moral, isto é, sua noção e seus elementos constitutivos. Depois, releva distingui-lo do dano patrimonial e dos reflexos patrimoniais do dano moral. São três situações jurídicas diferentes.

Bem jurídico é tudo o que pode ser objeto de uma relação jurídica. A expressão se refere a todos os valores que formam o constitutivo real do direito. Nesse sentido, os valores podem ser de ordem material ou moral. É o que esclarece Pierre Pescatore ao enunciar os valores relativos à vida jurídica: valores humanos, inerentes à própria pessoa, coisas corpóreas, valores imateriais, prestações de outrém, pecuniárias ou não, ofícios e funções da vida, comercial ou pública. ${ }^{7}$

Assim sendo, o objeto de toda a relação jurídica pode se integrar de bens materiais ou imateriais. Os bens materiais vêm a constituir o patrimônio. Este é conjunto de direitos e obrigações economicamente apreciáveis de que são titulares as pessoas. Os bens imateriais, ou seja, o conjunto de direitos de caráter pessoal, insuscetíveis de apreciação econômica, não integram o patrimônio. Este diz respeito apenas aos bens que têm expressão pecuniária. Os bens imateriais compõem, com mais propriedade, o estatuto da pessoa. O estatuto, diz Pierre Pescatore, "é $o$ conjunto de direitos e obrigações não-pecuniárias, de valor antes de tudo moral" 8 $\mathrm{O}$ conjunto dos direitos patrimoniais de uma pessoa forma o seu patrimônio. $\mathrm{O}$ conjunto de seus direitos extrapatrimoniais determina o seu estatuto. É tambem a lição de Caio Mário da Silva Pereira. Aliás, tais considerações justificam a classificação dos direitos subjetivos em patrimoniais, abrangendo os reais e creditórios e direitos extrapatrimoniais, que incluem os direitos de personalidade, os intelectuais e os potestativos.

Assim sendo, podemos aferir o inegável alcance da noção pesquisada: a que se refere ao dano moral. Dano é o desvalor do injusto. É toda a lesão a

7. Pierre Pescatore, Introduction a la Science du Droit, Luxembourg, p. 238, 1960.

8. Idem, ob. cit., p. 270 e ss.; Caio Mário da Silva Pereira, Instituições de Direito Civil Forense, v. I, la ed., p. 339. 
componentes dos valores de convivência social visados pela teleologia do sistema normativo. Dano, no entender de Hans Albrecht Fischer, é "todo o prejuízo que o sujeito de direito vem a sofrer através de violação de bem jurídico. Quando os bens jurídicos atingidos e violados são de natureza imaterial, verifica-se o dano moral" 9 Por exclusão, é toda a lesão a direitos estranhos ao patrimônio material, isto é, ao complexo de relações jurídicas que comportam aferição econômica. $\mathrm{O}$ dano moral se manifesta na esfera valorativa da pessoa, atingindo bens que constituem o apanágio do seu estatuto ontológico. É o que salienta Karl Larenz: "dano moral é o dano direto que alguém sofre em um bem da vida (como a saúde, o bem-estar corporal, a liberdade, a honra), que não pode ser apreciado em bens materiais" ${ }^{10}$ Constitui atentado à esfera afetiva e à esfera social da personalidade. Atinge os componentes da personalidade e os componentes do prestígio social inerentes ao ser humano. Atinge o psiquismo, a consideração social, em suma, a auto-realização e o autodesenvolvimento da pessoa humana.

Nesta ordem de considerações, é insuscetível de ser economicamente apreciável. O valor que ele atinge é, por natureza, imensurável.

O dano patrimonial é exatamente o oposto: atinge somente objeto de relações jurídicas que tenham expressão pecuniária. $\mathrm{O}$ titular de um bem jurídico patrimonial aufere, dele, indiscutivelmente, vantagem econômica.

Contudo, é possível que a ofensa a um bem jurídico extrapatrimonial venha a gerar para o seu titular reflexos de natureza econômica. A mesma lesão que afeta a esfera valorativa da pessoa pode atingir também sua esfera econômica. Um mesmo fato ilícito pode acarretar, como comumente ocorre, danos morais e danos patrimoniais, conjugadamente. O lesado vem a sofrer, ao lado do abalo moral e, em consequiência deste, redução do patrimônio natural. Podem ocorrer, realmente, estas hipóteses: a. prejuízo patrimonial; b. prejuízo moral; c. prejuízo moral com repercussão patrimonial. Neste último caso, costuma-se falar em reflexos patrimoniais do dano moral. Tais reflexos não passam de danos materiais, sendo, como tais, indenizáveis. Há, na hipótese, danos morais e patrimoniais. São os reflexos patrimoniais do dano moral. O dano é moral, mas, por reflexo, repercute na

9. Hans Albrecht Fischer, A reparação dos danos morais no Direito Civil, trad. Antonio Arruda Ferrer Correia, Armenio Amado Ed., Coimbra, p. 61e ss., 1938.

10. Karl Larenz, Derecho de Obligaciones, trad. J. Santos Briz, Ed. Rev. de Derecho Privado, p. 193 e ss. 
esfera patrimonial. Tais reflexos devem ser indenizados, como os danos materiais propriamente ditos.

Do exposto, segue-se que a expressão dano moral tem conteúdo específico: abrange somente o agravo a bens jurídicos materiais que, considerados em si mesmos, não afetam a esfera econômica do lesado. O dano moral não é de natureza econômica. Por isso, discute-se a respeito da possibilidade e eficácia das medidas de ordem reparatória.

O dano moral exige, no entanto, satisfação compensatória e pena privada; o dano material e os reflexos patrimoniais do dano moral constituem objeto de indenização. No primeiro caso, face à impossibilidade de reparação do dano, a sanção é compensatória. Representa medida de reação da ordem social, que deseja a integridade dos valores individuais e sociais da pessoa humana (integridade psicossomática) e medida de desestímulo à prática de ofensas que agridam a dignidade da pessoa. Representa, ainda, uma satisfação compensatória à vítima. Trata-se mesmo de sanção imperfeita. Cumpre, aliás, relembrar o caráter aproximativo de toda e qualquer sanção. No segundo caso (hipótese de danos materiais e dos reflexos patrimoniais do dano moral), a reparação implica em indenização dos prejuízos causados, medida de ressarcimento dos direitos transgredidos.

A concepção exposta possibilita distinguir o dano moral do dano patrimonial, permitindo, por outro lado, extremá-lo dos reflexos patrimoniais do dano moral.

3. Fundamento: auto-realização da pessoa humana.

O dano moral decorre de ações realizadoras de responsabilidade ex contractu e ex delicto. Mas o fundamento da responsabilidade advém da injustiça de condutas que afetam os valores da esfera moral do ser humano. Realmente, o dano moral é lesão a componentes do complexo valorativo da pessoa.

Entendemos que o Direito não pode descurar da defesa dos valores implicados na idéia de dignidade da pessoa humana. Não cabe ao Direito apenas a defesa do acervo dotado de economicidade. Cabe-lhe, principalmente, resguardar o patrimônio moral. 
Por isso, a fundamentação do dano moral reside, em última análise, nos preceitos do jus naturae. É exigência dos princípios do Direito Natural que as ofensas à personalidade e à consideração social do lesado sejam reprimidas.

Isto posto, cabe a pergunta: quais são as dimensões da pessoa? $O$ dinamismo psíquico, segundo ensina Joseph Nuttin, se desenvolve em três níveis: no nível psicobiológico; no nível psicossocial; e no nível psicoespiritual. No nível psicobiológico, encontram-se o impulso de autoconservação e o impulso sexual; no nível psicossocial, temos o impulso de sociabilidade e de auto-afirmação; no nível psicoespiritual, podem ser mencionados o impulso de cogitação do sentido da vida e o de autotranscendência. ${ }^{11}$ Estes níveis constituem as tendências e inclinações que impulsionam o ser humano à sua perfeição pessoal. ${ }^{12} \mathrm{O}$ injusto impedimento ao normal desenvolvimento desses impulsos vem a afetar o ser humano na sua personalidade individual e na personalidade social. No primeiro caso, atinge o ser humano como pessoa, isto é, como ente dotado de autonomia quanto ao ser, de autoconsciência, de comunicação e de autotranscendência, consoante esclarecimentos de Battista Mondin. ${ }^{13}$ No segundo, atinge o ser humano, na sua convivência social, como socius, no seu modo de atuar como pessoa envolvida no complexo dos papéis sociais. Atinge o ser humano como pessoa social. É o que ensina Joseph H. Fichter. ${ }^{14}$ Tais inclinações, constituindo a base para a determinação do justo natural, fundamentam a devida proteção a ser conferida ao ser humano pelo sistema normativo. Assim sendo, o fundamento da reparação dos danos morais encontra-se no estatuto ontológico da pessoa, cujos valores devem ser necessariamente resguardados.

Nesta ordem de considerações, para melhor fixar os contornos dos danos morais convém salientar que os mesmos atingem as esferas do psiquismo individual e do prestígio social. Não cabe defini-lo por exclusão relativamente aos danos materiais. Cumpre indicar seus componentes reais. Nesse sentido, pode-se adotar, como ponto de apoio para o desenvolvimento do trabalho, a conceituação dos irmãos Henri, Leon e Jean Mazeaud, segundo a qual constituem danos morais os

11. Joseph Nuttin, Psicanálise e Personalidade, trad. Geraldo Servo, Agir, p. 313 e ss.

12. Jacques Maritain, L'Hommme et l'État, Presses Univ. de France, p. 69-95.

13. Battista Mondin, O homem, quem é ele?. Elementos de Antropologia Filosófica, Paulinas, p. 295-8.

14.Idem, Sociologia, Herder, p. 45, 1967. 
que atingem o indivíduo na sua honra, reputação e consideração e os que o atingem na parte afetiva do patrimônio moral, causando-lhe lesões na esfera íntima do psiquismo. $^{15}$

4. Principais objeções doutrinárias à teoria da reparação.

Do exposto, segue-se que compete ao sistema normativo a proteção dos valores indispensáveis à convivência humana. Trata-se de exigência do jus naturae. Não se pode compreender, nesta linha de raciocínio, a limitação da tutela jurídica, aos atentados a bens materiais. A proteção deve ser ampla, abrangendo, também, reparo às injustas lesões que venham a afetar bens imateriais, consubstanciados no conceito acima exposto.

$\mathrm{O}$ art. 159 do Código Civil brasileiro, conceitua o ato ilícito como segue: "aquele que, por ação ou omissão voluntária, negligência, ou imperícia, violar direito, ou causar prejuizo a outrém, fica obrigado a reparar o dano" No nosso entender, a expressão direito tanto se refere aos direitos patrimoniais quanto aos extrapatrimoniais. E a expressão dano também abrange danos materiais, decorrentes de lesões que afetam o patrimônio, e danos morais, decorrentes de lesões que afetam o estatuto da pessoa. Pensamos que o sentido da lei alcança o mundo do ser e o do ter.

O conceito de dano é indivisível. A distinção entre dano material e dano moral diz respeito exclusivamente aos efeitos do dano. É o entendimento de Alfredo Minozzi. ${ }^{16}$ No mesmo sentido, a lição de Hans Albrecht Fischer, segundo a qual a lei, ao se referir a danos cogita de ambas as modalidades conhecidas, não se podendo relegar a segundo plano as lesões de ordem extrapatrimonial. ${ }^{17}$

A norma em questão protege os valores materiais e os valores morais. Realmente, ambos compõem, em última análise, a teleologia do sistema.

Por isso, o nosso Código, ao usar a expressão dano, sem qualquer qualificativo, acolheu a tese da reparação do dano moral. Não cabe ao intérprete

15. Mazeaud, Henri e Leon, Traité théorique et pratique de la responsabilité civile, delictuelle et contractuelle, Paris, p. 317, 1948.

16. Idem, ob. cit., p. 276.

17. Idem, ob. cit., p. 276. 
distinguir onde a lei não distingue. Simples interpretação semântica autoriza semelhante conclusão.

Surgiram, no entanto, algumas objeções, de ordem doutrinária, à tese da reparação do dano moral. As oposições clássicas são as de Gabba e Chironi. Para Gabba, os danos morais, embora considerados separadamente dos danos patrimoniais, têm origem na mesma causa. Além disso, não podem ser estimados pecuniariamente. ${ }^{18}$ Segundo Chironi, a indenização deve ser atribuída apenas aos danos patrimoniais, acrescentando que a sentença condenatória criminal é suficiente para reparar a ofensa moral sofrida pelo lesado. ${ }^{19}$

Contudo, tais objeçð̃es não procedem porque, embora as obrigações sejam desprovidas de natureza patrimonial, pode a sanctio juris correspondente à lesão ser prudencialmente fixada, em valores econômicos, como medida de caráter punitivo e satisfatório. Os argumentos dos que negam a possibilidade de reparação têm sido assim enumerados: a. inadequação da reparação pecuniária; b. dificuldade de configuração do direito violado; c. ausência de critério de medida para avaliar a equivalência exigida pela justiça comutativa; d. dificuldade de prova das lesões; e. indeterminação do número de sujeitos passivos; f. ilimitado poder conferido ao magistrado na apreciação do ilícito e na fixação da medida compensatória.

Vejamos, de per si, cada uma delas. No que se refere à primeira (inadequação da reparação pecuniária), cumpre ressaltar que, na hipótese, não se trata de indenização. Esta é cabível para o ressarcimento dos danos patrimoniais e dos reflexos patrimoniais do dano moral (estes são indenizáveis como danos patrimoniais). No caso em estudo, a sanctio juris é simples medida que consubstancia satisfação compensatória e pena privada. Além do mais, a sanção é consequiência da violação do preceito, representando, em matéria de personalidade, autorais e familiares, satisfação moral ao lesado e medida de eficácia para o cumprimento da ordem jurídica globalmente considerada. As sançð̃es, em muitos casos, são incompletas e inadequadas, como salienta Pierre Pescatore. Mas, são necessárias para manter a ordem jurídica e garantir os direitos individuais. As sanções têm sempre um caráter aproximativo no que se refere à eficácia dos preceitos referidos. $^{20}$

18. Idem, ob. cit., p. 54.

19. Idem, ob. cit., p. 257.

20. Idem, ob cit., p. 404. 
Quanto à segunda objeção, referente à incerteza do direito violado, basta considerar que a configuração desse direito é simples problema de subsunção. $\mathrm{O}$ dano moral é a violação de um bem jurídico normativamente previsto. $\mathrm{O}$ ordenamento jurídico, ao reconhecer aos membros da comunidade, direitos subjetivos extrapatrimoniais, tipifica os elementos necessários à sua configuração. É questão de tipicidade. Logo, o direito violado não é incerto. O desvalor do injusto não pode ser relegado pela ordem jurídica. Sua estrutura desponta do sistema jurídico.

A impossibilidade de reparação pecuniária, a que se refere a terceira objeção, está superada. Com efeito, não se trata, na hipótese, de estabelecer a equivalência para ressarcir o prejuízo. Este é inestimável por se referir a valores da pessoa. A idéia de quantificação é estranha ao mundo dos valores. Com redobrada razão, quando diz respeito aos valores relativos ao ser humano, sua personalidade e prestígios sociais. Mas, no caso de ofensa a direitos extrapatrimoniais, a sanção não é semelhante a que corresponde a direitos patrimoniais, porque, nestes, em tese, a estimativa econômica é possível. A sanção correspondente aos danos morais é de outra ordem; ela consubstancia uma medida de ordem compensatória e pena privada. Seu objetivo é o de atender ao postulado do Direito Natural, segundo o qual, em atenção à defesa dos direitos humanos e à manutenção do bem comum, a ofensa deve ser reparada através de medidas adequadas. A sanção tem outro objetivo, diverso do que se refere à equivalência de ordem econômica entre a ação danosa e o evento lesivo. Sua função é a de assegurar o respeito às prescrições da ordem jurídica, que não pode permanecer inerte às transgressões que atentam à dignidade da pessoa. Cabe também uma satisfação à pessoa do lesado. Aliás, é esta a função dos exemplary damages da Common Law.

A quarta objeção se refere à dificuldade de prova das lesões. Atualmente, tem-se entendido que a prova do prejuízo é dispensável já que ele advém da ocorrência da própria transgressão. A verificação da relação causal entre a ação e o resultado é suficiente para evidenciar os reflexos na esfera jurídica do lesado. Não há que se cogitar de prova do caráter atentatório à dignidade, inerente ao dano moral. É certo que o ilícito, atingindo a esfera afetiva do lesado deixa marcas indeléveis (danum in re ipsa). Trata-se de presunção absoluta. Está superada a objeção.

No que se refere à indeterminação do número de pessoas atingidas, cumpre relembrar que a titularidade depende de requisitos atinentes à caracterização 
do dano moral, o que deve ser examinado individualmente. $O$ dano pode atingir diretamente a determinadas pessoas e indiretamente a outras. Cada titular é pessoa autônoma, de modo que a verificação da hipótese de danos indiretos fica na dependência da análise relativa ao reflexo na esfera afetiva ou na consideração social de cada pretensor. Inexiste solidariedade entre os sujeitos passivos.

A última objeção é a que diz respeito ao ilimitado poder concedido ao magistrado para a fixação das medidas compensatórias. Entendemos que toda sentença é, em última análise, um ato de construção prudencial: de construção, porque o magistrado converte a norma genérica da lei na norma individualizada da sentença; e prudencial, porque, nesta passagem, intervém a apreciação das circunstâncias contingentes de cada caso, relevantes para o equacionamento da hipótese sub judice. Em toda a sentença se manifesta a eqüidade. Esta é o justo concreto exigido pelos litigantes. A fortiori, o critério que deve prevalecer para a composição dos danos morais que, por sua natureza, exige exame especial, sendo o prudente arbítrio judicial a medida mais salutar. Pode o legislador traçar norma de direito estrito, prefixando os valores a serem sopesados. Pode também se valer dos standards. Mas o juiz tem sempre poderes normativos, recebidos do ordenamento jurídico, por delegação, para compor a sentença.

5. O princípio da reparação no Direito Comparado.

Como tivemos oportunidade de salientar, são os princípios do jus naturae, que fundamentam a reparação do dano moral. No processo de positivação do direito, a matéria tem sido objeto de diferente tratamento, nos diferentes sistemas normativos. Importa, pois, analisar a questão, ainda que sumariamente, no Direito Comparado. Alguns sistemas, mediante critérios taxativos, têm negado reparação a certas hipóteses de dano que se enquadram no conceito acima enunciado. Nosso estudo se limita à análise dos ordenamentos que se filiam ao sistema romanístico, germânico e anglo-norte-americano, os quais apresentam soluções que podem ser confrontadas com as do nosso sistema legal. Alguns possibilitam ampla reparabilidade; outros limitam a compensação a casos expressos.

Cabe salientar que, no sistema de origem germânica, se destaca a solução dada pelo Direito suíço e, no sistema da Common Law, a dos Estados Unidos da América, pois, em ambos os ordenamentos, prevalece a tese da ampla 
reparabilidade. Neste último, a reparação é objeto de pura construção jurisprudencial.

Realmente, não há motivo para a exclusão do princípio da ampla reparabilidade já que, como demonstramos, caem ambas as lesões (materiais e morais) dentro da competência do Direito. Segundo a doutrina, o objeto do direito é sempre um valor, que pode ser de natureza econômica, como de natureza espiritual, como é o caso dos bens relativos aos predicados humanos. Surgindo o desvalor do injusto a reparação se impõe em ambas as hipóteses. Os direitos extrapatrimoniais merecem idêntico resguardo.

Nesse sentido, cabe proclamar a excelência do princípio firmado no Código Civil suíço. Este sistema possibilita a reparação adequada de todo dano moral devidamente configurado. O princípio vem expresso em lei sem limitações. Revelam-se, por outro lado, insuficientes os sistemas que, em virtude qualquer numa das objeções acima estudadas, restringem os casos de reparação, deixando de lado situações de verdadeiros danos morais.

Vejamos, porém, os diferentes sistemas. Cabe, de início, um estudo dos que se filiam ao sistema legislado e das que integram o direito costumeiro.

A solução decorre do estilo de cada sistema ou da mentalidade jurídica que o inspira. No direito costumeiro, prevalece um modo de pensar indutivo, porque as regras (rules) decorrem de elementos advindos da casuística. Para a decisão, o juiz considera os precedentes singulares (precedents), procurando reconhecer neles a norma para a solução dos problemas jurídicos concretos. O magistrado descobre 0 princípio normativo após trabalho artesanal de pesquisa de precedentes.

Considerando os ordenamentos filiados ao sistema legislado, podemos dizer que as legislações apresentam tipificações normativas dissonantes. Assim, algumas legislações consagram, como norma expressa, o princípio da reparação dos danos morais, o qual se projeta, por simples dedução, em diversas áreas. É o caso do Direito suíço e do Direito japonês. Outras, ao contrário, são destituídas de previsão expressa, sendo o princípio da reparação emergente da teleologia imanente ao sistema, obtido através de métodos hermenêuticos adequados, servindo, como exemplo, para o caso, o Direito francês, o belga e o espanhol. Finalmente, uma terceira categoria é a das legislações que só permitem a reparação em casos taxativamente previstos, podendo ser lembrados, na hipótese, os Direitos alemão, polonês e italiano. Estes não permitem a latitude de aplicação que proporcionam os sistemas anteriores. $\mathrm{Na}$ verdade, os ordenamentos que se filiam ao sistema legislado 
podem ser classificados, para os efeitos do sistema reparatório, em ordenamentos que contêm normas flexíveis e ordenamentos que contêm normas rígidas. Os que contêm normas flexíveis podem, por sua vez, ser subdivididos em ordenamentos que adotam o princípio normativo com ampla aplicabilidade e ordenamentos que não consagram o princípio, mas possibilitam, por indução amplificadora, extraí-lo das normas particulares das instituições. Os que contêm normas rígidas são casuísticos, só permitindo a reparação nos casos expressos, consoante adequada configuração tipológica. Vamos examiná-los.

Sistemas que contêm normas expressas são, como dissemos, o Direito suíço e o Direito japonês. Pode-se afirmar que o princípio da reparação é consagrado com ampla generalidade no Código Civil suíço. Sempre que alguém experimentar lesões a bens materiais tem direito a uma reparação nesse sistema. Como esclarecem Konrad Zweigert e Hein Kötz, o recurso a cláusulas gerais e standards, que exigem complementação na esfera judicial, constitui característica do Código Civil suíço. Este sistema normativo, ao se referir a interesses pessoais possibilita adequada concretização por parte do juiz. É o que se lê nos artigos 28 , I do Código Civil e 49 do Código das Obrigações. Este último diz, in verbis: "Celui qui subit une atteinte dans ses interets personnels pêut réclamer en cas de faute des dommages-intêrets et, en outre, une some d'argent à titre de reparation morale lorsque celle-ci est justifié par la gravité particulière du préjudice subi et de la faute" ${ }^{21}$ A disciplina dos casos fica a cargo do prudente arbítrio do juiz. Da mesma forma, o Japão adotou o princípio, inscrevendo-o assim em seu Código: "Celui qui, em vertu des dispositions de l'article précédent, doit des dommages-intêrets est tenu de réparer le dommage même non pécuniaire qu'il a causé, sans distinguer si le lésion a eu pour objet le corps, la liberté ou l'honneur d'une personne, ou si elle est portée a ses droits patrimoniaux" É a lição de Wilson Mello da Silva. ${ }^{22}$ O preceito normativo é, como no sistema suíço, apto a alcançar todas as hipóteses possíveis de lesões à esfera moral resultantes de direitos subjetivos normativamente consagrados. Além desses sistemas, consagram idêntico princípio os Códigos português (art. 496), mexicano (art. 1.916) e argentino (arts. 522 e 1.078).

Mas, ao lado de sistemas que contam com preceitos normativos expressos, coexistem aqueles que não se referem à reparação específica do dano

21. Konrad Zweigert e Hein Kötz, ob. cit., p. 212-3.

22. Wilson Mello da Silva, O Dano Moral e Sua Reparação, Forense, p. 229-31, 1983. 
moral, possibilitando, porém, a solução compensatória, através da interpretação do conjunto normativo. Neste caso, a indenização resultaria de processo de interpretação semântica, sistemática e teleológica do ordenamento. Tais sistemas se referem ao dano in genere. É o que ocorre, verbi gratia, com os sistemas francês, belga e espanhol.

Segundo o Direito francês, a indenização por dano moral decorre da interpretação doutrinária e jurisprudencial das normas referentes a contratos e delitos ou quase-delitos. Os preceitos que dizem respeito à responsabilidade extracontratual assim se expressam: "Tout fait quiconque de l'homme qui cause à autrui un dommage, oblige celui pour la faute duquel il est arrivé, a la reparer" (art. 1.382); e "chacun est responsable du dommage qu'il a causé non seulement par un fait, mais encore par sa négligence au par son imprudence" (art. 1.383). A responsabilidade contratual decorre, por sua vez, de outro preceito. É o seguinte: "Toute obligation de faire ou de ne pas faire se résout en dommages-interêts en cas de inexécution de la part du débiteur" (art. 1.142).

Os citados dispositivos não se referem à satisfação dos danos morais. Não há um princípio que a consagre. Mas a indenização repousa na interpretação que a doutrina e a jurisprudência apresentam relativamente à inexecução das obrigações (art. 1.142) e aos atos ilícitos (arts. 1.382 e 1.383). A indenização, em ambas as hipóteses, alcança os danos morais, já que os esquemas normativos se referem a dommages sem outros qualificativos ou restrições. $\mathrm{O}$ princípio da reparação, decorrente da análise semântica, bem como de considerações sistemáticas e teleológicas, foi acolhido na jurisprudência, como nos informa Georges Ripert. ${ }^{23}$

$\mathrm{Na}$ Bélgica, a doutrina e a jurisprudência têm adotado idêntica possibilidade de reparação, graças à interpretação semântica do termo dommage a que se refere o Código. É o que esclarece José de Aguiar Dias. ${ }^{24}$ No que se refere ao Direito espanhol a indenização decorre do entendimento que se tem dado ao art. 1.092 do seu Código Civil, que diz: "El que por acción causa daño a otro, interveniendo culpa o negligencia, está obligado a reparar o daño causado" Inexiste referência expressa ao dano moral. Mas a expressão é interpretada sem restrição de modo a abranger o dano moral. É o entendimento da jurisprudência que, à semelhança dos sistemas francês e belga, tem acolhido a tese da reparação.

23. Georges Ripert, La Règle Morale dans les Obligations Civiles, Paris, Lib. Générale, $4^{\natural}$ ed., p. 181,1949

24. José de Aguiar Dias, Da Responsabilidade Civil, $9^{\mathrm{a}}$ ed., v. II, p. 750. 
Não se justifica, mais, o apego à noção de caráter restrito, que procura ligar a noção de dano à ofensa ao conjunto de direitos e obrigações economicamente apreciáveis. Dano é a lesão a um bem-jurídico. É o resultado da antijuridicidade. Abrange toda e qualquer lesão a direitos, de ordem patrimonial ou extrapatrimonial.

É toda a lesão decorrente de injusto típico.

Assim, estudamos dois sistemas: os que contêm preceito expresso e os que, não contendo tais preceitos, possibilitam a reparação em virtude de princípios gerais, extraídos por via de análise indutiva, dos preceitos disciplinadores das instituições.

No terceiro grupo de sistemas, a reparação dos danos morais está vinculada à descrição normativa dos tipos de lesão a bens espirituais. A reparação depende de subsunção a modelos legais, devidamente tipificados. É o que ocorre com os sistemas alemão, polonês e italiano.

O sistema alemão, como esclarecem Konrad Zweigert e Hein Kötz, adota, como técnica normativa, a descrição acurada de toda a infração, reduzindo, assim, o poder discricionário do magistrado. ${ }^{25} \mathrm{O}$ Código Civil alemão enumera, taxativamente, os casos de indenização. Diz o art. 253: "Pour un dommage qui n'est pas un dommage partrimonial, le dedommagement en argent ne peut être poursuivi que dans les cas fixés par la loi" As hipóteses normativas, como ensina Hans Albrecht Fischer, são as que se encontram previstas nos arts. 847 e 1.300 do Código, abrangendo três grupos de situações, a saber: lesões que afetam a integridade corporal ou a saúde; privação da liberdade; e, finalmente, violação da honra sexual da mulher. ${ }^{26} \mathrm{~A}$ reparação dos danos morais se encontra restrita às hipóteses do BGB.

No sistema italiano, a matéria está prevista nos arts. 2.059 e 2.043 do Código. Diz o primeiro texto legal: "Il danno non patrimoniale deve essere resarcito solo nei casi determinati dalla legge" O segundo assim se enuncia: "Qualunque fatto doloso o culposo, che cagiona ad altri un danno ingiusto, obbliga colui che ha commesso il fatto a risarcire il danno" O dispositivo inicial tem caráter restritivo já que limita a indenização aos casos taxativamente previstos, enquanto que o segundo, aludindo à indenização do dano, permite abranger as hipóteses de danos morais, além dos que constituem objeto de tutela expressa. Como esclarece Andrea Torrente, o dano moral comporta ressarcimento quando o fato que

25. Idem, ob cit., p. 212.

26. Idem, ob cit., p. 259 e ss. 
lhe deu causa, de natureza contratual ou extracontratual, é o previsto na lei, como crime ${ }^{27}$ No mesmo sentido é o entendimento de Alberto Trabucchi. O ressarcimento do dano moral, esclarece o mencionado jurista, não tende à restituição in integrum, mas a uma sanção satisfatória apenas nas hipóteses previstas na lei como crimes. ${ }^{28}$

Nestas condições, no Direito italiano, o ressarcimento do dano moral apenas existe na hipótese de o ilícito civil, que dá ensejo ao dano extrapatrimonial, ser conexo com o ilícito penal. Semelhante previsão normativa foi criticada por Giuseppe Bettiol, in verbis: "Una tale disciplina del risarcimento del danno non patrimoniale è quanto mai irrazionale, perché fa dipendere il risarcimento del danno stesso dalla circonstanza della connessione di un illecito con l'altro, nella falsa suppozione che sia il reato a determinare l'obbligo di subire le sanzioni civili. Cosí è risarcibile solo in danno non patrimoniale derivante da illecito civile, quando tale illecito si sostanzi in un fato materiale che è contemporaneamente anche lesione di un interesse penalmente tutelato", ${ }^{29}$

$O$ sistema polonês segue idêntico critério: 0 da previsão expressa dos casos de indenização por dano moral. O art. 157 do Código das Obrigações diz expressamente que a satisfação por danos morais só pode ser obtida nos casos previstos em lei. Por sua vez, os arts. 165 e 166 limitam a indenização às seguintes hipóteses: lesão corporal, perturbação da saúde, privação da liberdade, atentado à honra e morte.

Estudados os sistemas de direito legislado cabe especial referência ao sistema costumeiro. No sistema da Common Law, a indenização dos danos morais decorre dos precedentes. Estes constituem as fontes formais do direito. Contudo, as declarações contidas nos precedentes constituem atos de criação normativa, quando revelam a ratio decidendi do caso examinado. Só nessa hipótese, a decisão vale como princípio jurídico obrigatório. Além disso o juiz pode extrair a decisão de princípios mais amplos de uma série de precedentes dispersos. É a metódica da Case Law. É o que esclarece Gustav Radbruch na sua obra El Espiritu del Derecho Inglés. ${ }^{30}$ Os precedentes vêm a ser, portanto, obrigatórios (rules of precedents). A statute low (direito escrito) é excepcional. Pois bem, dos referidos precedentes se

27. Andrea Torrente, Manuale di Diritto Privato, Giuffrè Ed., p. 572-3, 1965.

28. Alberto Trabucchi, Istituzioni di Diritto Civile, Cedam, $27^{\text {a }}$ ed., p. 217, 1983.

29. Giuseppe Bettiol, Diritto Penale, Cedam, $7^{\circledR}$ ed., p. 765-6, 1969.

30. Gustav Radbruch, El Espiritu del Derecho Inglés, p. 38-9. 
extrai, no caso em estudo, a norma que deve ser amplamente acolhida a indenização por dano moral.

A construção jurisprudencial da Common Law tem acolhido o ressarcimento das les̃̃es que afetam valores morais, dimensionando, em cada caso concreto, as compensações integrantes dos punitives ou exemplary damages.

6. Análise normativa: as transgressões, as sanções, os obrigados e os pretensores.

Vamos partir, para o exame dos danos morais, dos elementos indicados pelo esquema de toda e qualquer norma prescritiva. A estrutura da norma jurídica é a seguinte: dado o fato jurídico deve ser a prestação jurídica; dada a transgressão jurídica deve ser a sanção jurídica. A primeira parte (norma primária) revela a conduta lícita; a segunda (norma secundária) diz respeito à conduta ilícita. Adotando esse esquema como critério de apreciação do tema em estudo, cabe-nos, agora, fixar nossa atenção no momento secundário, isto é, no que se refere às transgressões que afetam os valores morais da pessoa e as sanções correspondentes a esses injustos típicos. Ao mesmo tempo, veremos os personagens ou sujeitos envolvidos na relação convivencial: os obrigados e os pretensores. A primeira parte do esquema normativo já decorreu do estudo precedente.

\subsection{As transgressões.}

Como demonstramos anteriormente, danos morais são aqueles que, afetando a esfera do psiquismo e a da reputação social (ser humano como pessoa individual e como pessoa social) obstaculizam seu normal desenvolvimento (autorealização). Atingem bens que integram a estrutura ontológica da pessoa. Bem é o que contribui para o normal desenvolvimento da personalidade. Dano moral é o ilícito que ocasiona lesão a bens para os quais tendem as inclinações e tendências naturais da pessoa humana.

Assim posta a questão, cabe melhor especificação. Cumpre indicar os modelos legais de transgressões que agridem referidos bens, isto é, os elementos objetivos e subjetivos que caracterizam o ilícito.

Releva indicar as condutas antijurídicas que podem ser atribuídas a uma pessoa, a título de dolo ou culpa, ou mesmo decorrente de simples risco, que tipificam o ilícito e acarretam responsabilidade ex contractu ou ex delicto. 
O nosso Código não contém previsão normativa das condutas antijurídicas que tipificam a infração. Mas, delineou a forma de ressarcimento de algumas espécies de danos morais. Assim, parece que seriam apenas estas as espécies legais. A casuística dos danos depende de análise dos preceitos que falam sobre a liquidação dos mesmos. As hipóteses seriam as que se referem ao homicídio, às lesões corporais (ferimento, ofensa à saúde, perda temporária parcial ou total e perda permanente da capacidade laborativa decorrentes dessas lesões); defeito hábil a comprometer de forma temporária (parcial ou total) ou permanente do exercício de ofício ou profissão; dano estético; calúnia, injúria ou difamação; ofensa à liberdade pessoal; violência sexual; ultraje ao pudor; e, finalmente, esbulho ou usurpação do alheio. É a lição de Caio Mário da Silva Pereira. ${ }^{31}$

O Código tipifica danos morais provenientes de ofensas a bens jurídicos que, por se referirem a valores fundamentais da vida social (bens vitais de convivência humana), configuram, também, ilícitos penais. Mas não há que estabelecer conexão entre ambos, porque os pressupostos da responsabilidade civil e penal são diferentes. Além disso, cumpre lembrar que a responsabilidade civil abrange não-só o dano originário de ilícito extracontratual (ex delicto), como o decorrente de inadimplemento de obrigação contratual (ex contractu).

Entendemos que a tipificação dos casos acima referidos (tipificação, aliás, indireta, porque implícita na forma de liquidação) não significa exclusão de outros casos não-contemplados. Razões de ordem doutrinária justificam semelhante assertiva. Com efeito, a ordem jurídica envolve, sob sua proteção, bens inestimáveis. É a lição de Jean Dabin que, incluindo os valores extra-econômicos na linha de proteção jurídica, salienta a necessidade de sua disciplina, apesar das dificuldades inerentes ao conceitualismo jurídico. ${ }^{32}$ Idêntico o pronunciamento de Caio Mário da Silva Pereira. ${ }^{33}$ Em segundo lugar, parece-nos que, além do amparo doutrinário, a interpretação de ordem semântica, sistemática e teleológica do Código possibilita afirmar que a proteção legal alcança, além dos casos previstos, toda e qualquer violação de bens jurídicos legalmente protegidos. É o que a seguir pretendemos demonstrar.

31. Caio Mário da Silva Pereira, Da Responsabilidade Civil, p. 337-46; Instituições de Direito Civil, v. I, p. 343; v. II, p. 285-9; e v. III, p. 512-3.

32. Jean Dabin, Théorie Générale du Droit, Nouvelle Ed., Dalloz, Paris, p. 148-9, 1969.

33. Idem, Instituições de Direito Civil, v. I, p. 343. 
Com efeito, os substantivos usados pelo legislador são portadores de um significado jurídico. Revelam conceitos jurídicos. O legislador; no processo de tipificação normativa, desprezou as notas contingentes e as espécies de dano, para ficar só com a essência deste. Em conseqüência, a expressão dano está carregada de especial significação. Dano é toda a ofensa a um bem-jurídico. Quando o bemjurídico atingido diz respeito à esfera valorativa da pessoa, o dano resultante é de ordem moral. Quando o bem-jurídico atingido diz respeito à esfera patrimonial, o dano resultante é de ordem material. Logo, há dois danos: o material e o moral. O nosso Código Civil abraçou a ambos, porque se utilizou da expressão dano sem outros qualificativos, de modo que este é o significado jurídico do substantivo. Nem cabe restringir onde a lei não restringe.

Esta é a conclusão da análise semântica. Sob o ponto de vista da análise sistemática, idêntica conclusão se impõe. O nosso Código, ao disciplinar o problema da liquidação dos danos (arts. 1.537 a 1.553) contemplou alguns casos de danos morais. Mas, não excluiu outros. Ressaltou, no art. 1.553 que a liquidação de outros casos deve ser feita por arbitramento. Isto significa o seguinte: para os casos previstos, o ressarcimento deve ser feito segundo critérios preestabelecidos; para os outros, a indenização depende de arbitramento. Logo, existem outros casos de ofensa a direitos subjetivos devidamente consagrados na ordenação sistemática.

Nesta ordem de idéias, forçoso é convir que a tese da reparabilidade do dano moral resulta do enunciado do art. 159 do Código Civil. Ampara esse ponto de vista Aguiar Dias, ao asseverar que não há razão alguma para se inferir que esse artigo tenha restringido a indenização ao dano material. ${ }^{34}$

O método sistemático também possibilita semelhante entendimento. Mencionando o Código algumas hipóteses não podiam excluir outras, porque a regra geral é a dos arts. 159 e 1.518. Além do mais, como preleciona Clóvis Beviláqua, o art. 76 do Código confirma a tese da reparabilidade. Diz o jurista: "Se o interesse moral justifica a ação para defendê-lo ou restaurá-lo, é claro que tal interesse é indenizável, ainda que o bem moral não se exprima em dinheiro" ${ }^{35}$ Em conclusão: toda a lesão ao direito é indenizável, já que o ordenamento jurídico consagra os direitos subjetivos integrantes da personalidade moral ao lado dos direitos subjetivos de ordem exclusivamente patrimonial. O Código protege o patrimônio e o estatuto

34. José de Aguiar Dias, ob. cit., v. II, p. 755.

35. Clovis Bevilaqua, ob. cit., p. 313. 
da pessoa. Mesmo porque, consoante o art. 75 do Código, a todo direito corresponde uma ação que o assegura. Logo, também existe ação para assegurar a reparação do ilícito que venha a atingir valores morais juridicamente consagrados.

Pode ser que o legislador não tenha pretendido chegar a estas conclusões. Mas, como pondera Silva Pereira, a interpretação teleológica não permite, no presente momento, conclusão diversa. Não pode ficar sem reparo transgressões que venham a atingir bens indisponíveis. ${ }^{36}$

O Código, estudado à luz dos valores sociais do presente, consagra o princípio da reparação dos danos morais. O enunciado normativo é o mesmo, mas as conotações valorativas que o sustêm são diferentes. Esta é a interpretação que decorre da regra do art. $5^{\circ}$ da Lei de Introdução ao Código Civil que preconiza a atenção aos valores sociais do momento de aplicação do preceito. Por outras palavras: as normas particulares devem ser entendidas de conformidade com a teleologia imanente ao sistema normativo a que pertencem.

Assim sendo, o casuísmo do Código não esgota as hipóteses de transgressões que ocasionam danos morais.

A descrição típica de todas as formas de ilícito é impossível. Inúmeras são as situações convivenciais tidas como antijurídicas e capazes de atingir valores morais e invadir a esfera do psiquismo individual e do prestígio social do ser humano. Inúmeras são as ações que podem obstaculizar o normal desenvolvimento da auto-realização da pessoa. As mais graves estão, de certo modo, contempladas na legislação civil.

No entanto, torna-se necessário precisar os contornos das situações que originam danos morais, através de fórmula hábil a abarcar os diversos tipos de ilícito que a vida convivencial venha a apresentar. Propomos a seguinte conceituação: constituem transgressões todas as condutas geradoras de descumprimento de deveres jurídicos de respeito às prerrogativas da pessoa, as quais acarretam lesões a direitos subjetivos não-patrimoniais referentes à esfera do psiquismo individual e reputação social, normativamente consagrados.

36. Idem, Da Responsabilidade Civil, cit., p. 64 


\subsection{As sanções.}

A análise normativa que vimos empreendendo deve enfrentar, agora, a segunda questão: a que diz respeito às sanções. Quais as sanções que correspondem às transgressões acima delineadas?

$\mathrm{Na}$ hipótese do dano moral, o prejuízo sofrido pela vítima é de ordem espiritual, insuscetível de medida econômica. Os valores espirituais, por sua própria natureza, são imensuráveis. É o que demonstra Johannes Hessen em seu Tratado de Filosofia. A nota característica desses valores é a impossibilidade de quantificação. A atribuição de um valor econômico a uma obra-de-arte representa, apenas, critério pragmático de troca. Ninguém pode apreciar, em dinheiro, o quantum de um valor estético. O mesmo ocorre com o dano moral. Deve haver um critério pragmático, para a estimativa compensatória da sanção. Por isso, a satisfação do dano moral, necessária à proteção dos valores da pessoa, é uma sanção aproximativa, isto é, se limita a compensar, dentro das contingências humanas e de modo pragmático, a lesão sofrida pela vítima. Tal solução já fora vislumbrada por Pedro Lessa que, em memorável voto, diz ser o meio imperfeito, mas o único realizável. ${ }^{37}$

Além do efeito satisfatório para o lesado, cumpre desestimular condutas antijurídicas. A ordem jurídica precisa reagir aos atentados aos bensjurídicos indispensáveis à convivência humana. A sanção é desagravo à ofensa, tendo caráter satisfatório e punitivo. É o que preconiza o jus naturae.

Nesta ordem da idéias, a sanção não tem por finalidade a reposição do patrimônio do lesado, mas a compensação do dano causado e desestímulo à prática do ilícito. Repousa no binômio: mera compensação pela ofensa do bem e punição do infrator.

A dificuldade de mensuração das sanções não pode servir de pretexto para afastar as medidas de proteção aos bens-jurídicos indisponíveis, que compõem o estatuto ontológico da pessoa humana.

Em virtude da relevância da questão relativa à fixação de parâmetros para a equitativa aplicação das sanções, a ele dedicaremos algumas considerações em capítulo especial.

37. Pedro Lessa. Rev. Forense, v. XXIV, p. 475. 
6.3. Os obrigados.

Obrigados e pretensores são os membros de toda e qualquer relação jurídica. Obrigados são aqueles que, tendo participado de fato jurídico normativamente previsto, receberam, do preceito normativo, deveres a serem cumpridos em benefício dos pretensores. Estão no polo passivo da relação jurídica. Pretensores, por sua vez, são aqueles que, tendo participado de fato jurídico normativamente previsto, receberam do ordenamento jurídico direitos que devem ser usufruídos sem impedimento por parte dos obrigados. Estão no polo ativo da relação jurídica.

Seguindo o esquema da norma jurídica, acima referido, trataremos, agora, dos obrigados à reparação do dano moral, indicando as pessoas física e jurídica que, descumprindo deveres a que estavam sujeitas, lesaram em seus bens os pretensores. À indicação destes últimos dedicaremos o capítulo seguinte.

Tais pessoas respondem, evidentemente, por fato próprio, por fato de outrém e por fato das coisas.

$\mathrm{Na}$ primeira hipótese (responsabilidade por fato próprio), respondem os agentes tanto por ocorrência de ilícito decorrente de violação contratual (responsabilidade contratual) quanto por ocorrência de ilícito proveniente da obrigação genérica de não-lesar a outrém (responsabilidade extracontratual).

A segunda hipótese, de responsabilidade pelo fato de outrém, é responsabilidade indireta, de caráter excepcional. Trata-se da responsabilidade dos pais pelos atos dos filhos menores; dos tutores e curadores pelos atos de seus tutelados e curatelados; dos empregadores pelos atos de seus empregados; dos donos de hotéis e similares, relativamente aos hóspedes, por atos de seus empregados; dos que, gratuitamente, tiram proveito do crime.

A terceira hipótese, chamada responsabilidade pelo fato das coisas (denominação tida como imprópria) abrange, segundo Silva Pereira, "aquelas situações em que a ocorrência do prejuizo origina-se de circunstâncias em que não é a ação direta do homem que determina o desfecho prejudicial, porém o acontecimento ou fato decorre de modo material" 38 
Além das pessoas físicas, podem ser responsabilizadas as pessoas jurídicas. À responsabilidade podem ser chamadas as pessoas de Direito Privado e as pessoas de Direito Público.

Vejamos, em primeiro lugar, as de Direito Privado. Ensina Silva Pereira que "as pessoas de Direito Privado, qualquer que seja a sua natureza e os seus fins, respondem pelos atos de seus dirigentes ou administradores, bem como de seus empregados e prepostos, que, nessa qualidade, causem prejuizo a outrém" 39 Todas as pessoas jurídicas de Direito Privado são, assim, responsáveis, não havendo distinção alguma a se fazer relativamente à finalidade de cada uma delas. Nesta ordem de considerações podem ser alinhados como responsáveis por danos morais as sociedades civis, as associações, as fundações, bem como as sociedades comerciais, em todas as suas modalidades.

No que se refere às pessoas jurídicas de Direito Público, a responsabilidade está consagrada no art. 15 do Código Civil, cujo princípio foi confirmado pelo art. 37, n. XXI da Constituição Federal. Mas, como ensina Silva Pereira, a questão deve ser examinada sob tríplice aspecto: o da responsabilidade por atos da administração pública; o da responsabilidade por atos praticados no exercício da função jurisdicional; e o da responsabilidade por atos legislativos. Todos esses atos, quando revestidos de ilicitude, podem ocasionar danos morais. Desta forma, há responsabilidade civil do Estado, decorrente da atuação dos órgãos que integram seus poderes. $\mathrm{O}$ ato administrativo, praticado sem observância dos princípios que condicionam sua existência (capacidade, motivo, finalidade, causa e formalidades), gera responsabilidade do Estado. Pode esse ato provir da Administração direta ou da Administração indireta (autarquias; empresas públicas; sociedades de economia mista, fundações públicas). $\mathrm{O}$ ato judicial pode decorrer do exercício da jurisdição ou ser de natureza administrativa. Quando o Judiciário pratica ato de natureza administrativa, a responsabilidade deve ser apreciada segundo os cânones já referidos, que regem os atos administrativos propriamente ditos. Quando a responsabilidade provém de ato jurisdicional, é preciso que o magistrado tenha agido com dolo ou culpa, como, aliás, está previsto no art. 133 do Código de Processo Civil. Só ato jurisdicional irregular é que dá origem à responsabilidade do Estado. Por fim, a responsabilidade dos órgãos legislativos decorre da inobservância, pelo Legislativo, dos cânones que informam o processo legislativo. Como ensina Silva 
Pereira, o Legislativo não pode transcender os limites da outorga constitucional. Se o Legislativo elabora provimento interno transgredindo direitos ou se vota lei, cuja inconstitucionalidade é declarada formalmente pelo Judiciário, a responsabilidade por lesões a direitos individuais pode ser reconhecida. ${ }^{40}$

Obrigados são as pessoas físicas ou jurídicas acima mencionada, quando transgridem a ordem jurídica, ocasionando lesões a direitos subjetivos atinentes à personalidade e integrantes dos componentes do psiquismo individual e do prestígio social.

\subsection{Os pretensores.}

Pretensores são os que, tendo participado de fato jurídico normativamente previsto, receberam do preceito normativo, prerrogativas ou faculdades, que devem ser usufruídas, sem injusto impedimento por parte dos obrigados. Ocorrendo, por parte destes últimos, invasão na esfera de ação dos primeiros, dá-se o ilícito. Os pretensores tornam-se, então, portadores de direitos subjetivos de segundo grau, podendo exigir, através da ação, a aplicação da sanctio juris. No caso em estudo são os titulares da ação cabível para exigir a satisfação decorrente dos danos morais. São os lesados que podem ser pessoas físicas ou jurídicas.

A tutela jurisdicional, nos casos acima referidos, provém de ação, de caráter privado a ser movida, individualmente, por quem se julgar ofendido.

Contudo, a doutrina passou a caracterizar, a partir dos estudos de Mauro Cappelletti, outro tipo de interesses, situados entre as categorias tradicionais, de interesses público ou privado. É a categoria dos interesses metaindividuais. São interesses comuns a certas categorias de pessoas, componentes de conjuntos indeterminados ou determináveis de titulares. Esses interesses não comportavam defesa única, concentrada, global. Só podiam ser objeto de ação em que, cada um, individualmente, defendia seu próprio direito. Inexistia defesa eficaz. Interesses metaindividuais são os que promanam de valores de convivência social considerados relevantes por atingirem grupos, classes ou agregados vinculados entre si por relação de fato ou de direito. Tais interesses podem ser coletivos, quando se referem a uma categoria determinada ou determinável de pessoas e difusos quando se referem a um 
grupo indeterminado de indivíduos, que não podem ser indicados, por serem dispersos no meio social. Valores protegidos, na espécie, são os que se referem à defesa do meio ambiente, do consumidor e do patrimônio cultural.

Tendo a doutrina delineado essa nova categoria de interesses, que não se enquadra na divisão tradicional de interesses em públicos e privados, estando, porém, a exigir proteção eficaz, adquiriram certos entes, a titularidade do direito de ação civil pública. Tem legitimidade ad causam o Ministério Público, a União, os Estados, os Municípios, as autarquias, as empresas públicas, as sociedades de economia mista, bem como associações privadas que incluam, entre suas finalidades institucionais, a proteção de interesses considerados coletivos ou difusos.

\section{Tipologia das transgressões.}

Consiste o dano moral, como já assinalamos, no evento lesivo decorrente da prática de ilícito que, atingindo valores jurídicos relativos a componentes do psiquismo individual e do prestígio social, reflete negativamente, no dinamismo da auto-realização da pessoa humana. Trata-se, na hipótese, de impedimento à plena realização dos valores sensíveis (vitais, hedonísticos e de utilidade) e espirituais (lógicos, estéticos, éticos e religiosos) na classificação de Johannes Hessen. ${ }^{41}$ Tais valores não possibilitam avaliação econômica, mas a conduta ilícita (desvalor) que impede sua normal expansão pode acarretar compensação satisfatória ou pena de ordem privada. Foi o que, ao longo do presente trabalho, procuramos demonstrar.

Importa, agora, descrever as ações que podem produzir os eventos lesivos que atingem os valores já mencionados. $O$ nosso sistema legal não as descreve. Pode-se dizer que, de um modo geral, tipificam esses injustos todas as ações capazes de subtrair valores referentes à personalidade do ser humano ou impedir o seu normal desenvolvimento. Tais ações emergem da negação de direitos subjetivos consagrados na ordenação sistemática, condicionando a responsabilidade ex contractu ou ex delicto.

Duas correntes doutrinárias procuram esclarecer o conteúdo desses ilícitos. Uma corrente restritiva, que não vislumbra danos morais em todos os atentados a direitos subjetivos que garantem a personalidade e a consideração social 
da pessoa, mas, apenas, em alguns deles, taxativamente enumerados. A outra, de caráter abrangente, que entende serem indenizáveis todos os danos morais devidamente caracterizados. Desnecessária seria a descrição dos elementos integrantes da conduta, porque esta resultaria da própria natureza do injusto impedimento aos direitos subjetivos já consagrados no sistema normativo.

$\mathrm{Na}$ verdade, a corrente denominada abrangente é a que no momento atual prevalece, já que inúmeras são as hipóteses de danos morais que vêm sendo reconhecidas pelos nossos Tribunais. Os danos morais atingem o complexo valorativo da pessoa. Decorrem do Direito Natural, recebendo, por acréscimo, o reconhecimento do Direito Positivo. Adquirem a característica de normas cogentes, sem perder a natureza do jus naturae. Não há como restringi-los às hipóteses capituladas no Código Civil, até porque a pretensão do Código, como dissemos, foi a de disciplinar apenas os fatores intervenientes na liquidação de alguns casos considerados de maior gravidade.

O nosso Código, no art. 159, se refere à violação do direito. E acrescenta que a esta violação deve se seguir a reparação do dano. Os direitos a que a norma se refere são os direitos subjetivos consagrados pela ordenação sistemática. Abrange, por via de conseqüência, os direitos subjetivos que protegem os valores espirituais da pessoa. À interpretação semântica,_sistemática e teleológica, cabe revelar o conteúdo desses direitos e, em conseqüência, apontar as ações injustas que impedem seu normal desenvolvimento.

Isto posto, pode-se dizer que configuram transgressões todas as ações finalisticamente encaminhadas a lesar os componentes do estatuto ontológico da pessoa, definidos pelo jus naturae e consagrados no Direito Positivo.

Voltemos, porém, nossa atenção às principais categorias de lesões. $\mathrm{Na}$ impossibilidade de uma enumeração completa, vamos enunciar, por via exemplificativa, as principais.

Cumpre, porém, seguir uma ordem: a da classificação das disciplinas jurídicas. Realmente, as lesões constituem violação de direitos subjetivos previstos em esquemas normativos integrantes de diferentes áreas do sistema. Adotando o critério preconizado por Pierre Pescatore (o que se refere à atividade humana regulada), o sistema jurídico divide-se em Direito Público, relativo à vida da comunidade política, Direito Privado ou Civil, relativo à vida pessoal e familiar e Direito Econômico e Social, relativo à vida profissional organizada. No Direito Público, temos o Direito Constitucional, o Direito Administrativo, o Direito 
Tributário e o Direito Penal. O Direito Privado abarca todo o Direito Civil. No Direito Econômico e Social, temos o Direito Econômico, o Direito Comercial, o Direito do Trabalho e o Direito Previdenciário. Esses ramos constituem o Direito Substantivo. A cada um deles corresponde um Direito Adjetivo. Destes, os principais são o Direito Processual Civil, o Direito Processual Penal e o Direito Processual do Trabalho.

Vejamos, de forma exemplificativa, os danos morais que podem ocorrer em virtude da violação de direitos subjetivos correspondentes às áreas acima referidas. A matéria está amplamente estudada na obra do juiz Rui Stocco, intitulada Responsabilidade Civil e Sua Interpretação Jurisprudencial, de onde retiramos os casos que se seguem.

$\mathrm{Na}$ esfera do Direito Constitucional, podem ser apontados danos que se referem às restrições indevidas de direitos políticos e eleitorais ou decorrentes de ofensas aos direitos e garantias individuais. No Direito Administrativo, podem servir de exemplo, impedimentos eventualmente oferecidos ao acesso por concurso a cargo público, lesões ocorridas no atendimento em hospitais da rede pública, descumprimento de obrigações contratuais, no dano resultante de tortura, no dano resultante de atos ilícitos praticados por servidores públicos. No Direito Tributário, temos os danos decorrentes de normas ilegais. No Direito Penal, podem servir de exemplos, os danos decorrentes de homicídio, danos à saúde, danos decorrentes de atos que atingem a liberdade pessoal e sexual.

$\mathrm{Na}$ esfera do Direito Civil, podem ser apontados ilícitos que atingem o direito de personalidade (direito à imagem, autoral, intelectual), ilícitos que afrontam aos direitos conjugais (injúrias graves, relação concubinária, agressões entre cônjuges), ilícitos que atingem a vida negocial (descumprimento de obrigações contratuais) e toda e qualquer lesão decorrente de ofensa ao princípio do alterum non laedere (responsabilidade por ato próprio, por ato de outrém ou pelo fato da coisa).

$\mathrm{Na}$ esfera do Direito Comercial, podem ser relembradas lesões que atingem direitos decorrentes dos atos e contratos comerciais, como, por exemplo, os que se referem a protesto indevido de título de crédito, à inclusão indevida de cliente de estabelecimento bancário em central de restrições a crédito, à devolução indevida de cheque por instituição financeira. No Direito do Trabalho, lesões que venham a afetar os direitos do trabalhador, na divulgação de segredo profissional. No Direito Previdenciário, as lesões decorrentes de acidentes do trabalho. 
Finalmente, na esfera do Direito Processual Civil, lesões decorrentes de erro judiciário, de litígio de má-fé. No Direito Processual Penal, podem servir de exemplo atos que consubstanciam prisões indevidas, execução de réu tido e havido como inocente, reparáveis por habeas corpus, mas que repercutem negativamente na esfera dos direitos de personalidade.

Em suma: o ser humano sofre danos morais quando é atingido nas diversas esferas de atividades acima enumeradas, a saber, a da vida política, a da vida pessoal e familiar e a da vida profissional.

\section{Eqüidade na mensuração da sanctio juris.}

O Código Civil não delineou um sistema para a mensuração das sanções relativas à compensação satisfatória e pena privada. $O$ equacionamento dessas medidas passa a ser tarefa relevante atribuída ao prudente arbítrio do juiz. Não há diretrizes ou standards oriundos do sistema legal.

Tem o juiz amplos poderes para fixar a forma e o quantum da reparação em cada caso concreto. Na verdade, o juiz completa a tarefa do legislador. É claro que muitos fatores hão de intervir na fixação das sanções.

Deve o juiz, com base no ordenamento jurídico, arquitetar e compor a solução concreta e justa para a hipótese de lesões aos valores de convivência social que fundamentam o sistema.

Entendemos que a prudência, como virtude do intelecto prático, permite unir o conhecimento especulativo ao prático, o abstrato da norma ao concreto da decisão. Por isso, a sentença é sempre um ato de construção prudencial.

Esta tarefa assume particular relevância na questão em estudo, porque o legislador não indicou os fatores que devem ser sopesados.

O juiz deve compor a norma individualizada da reparação dos danos morais. Seu critério é sempre o da eqüidade.

-Pierre Pescatore assim se expressa: "para os práticos (do Direito) é necessário, antes de tudo, discernir a realidade dos fatos e das circunstâncias concretas, manejar as regras de direito com inteligência e fazer um emprego judicioso do poder discricionário que lhe é deixado. Sua arte é a da prudência jurídica, a juris prudencia, no sentido etimológico do termo" 42

42. Idem, ob cit., p. 47-48. 
Alguns autores dizem que esta situação implica na concessão de excessivo poder ao magistrado, devendo, por isso, a atuação judicial se limitar à aplicação da sanctio juris a casos especiais. Não pode haver, segundo entendem, ampla reparabilidade, decorrente da proclamada análise sistemática. Dizem mais que o critério da eqüidade deve ser aplicado somente quando há previsão expressa. No nosso sistema a aplicação da eqüidade estaria condicionada à regra do art. 127 do Código de Processo Civil.

Entendemos, data venia, que toda e qualquer decisão judicial é fruto da eqüidade. Desnecessária é a previsão normativa para sua aplicação e logicamente impossível sua limitação. O juiz complementa a obra do legislador, contribuindo para o progresso e desenvolvimento do sistema normativo. Isto ocorre em todas as decisões. Com mais razão, há de ocorrer nas decisões que, em virtude de ausência de orientação legal, foram deixadas ao prudente arbítrio do juiz. Quando o legislador se utiliza de standands e quando, sem traçar diretrizes, deixa a questão ao arbítrio do juiz, a eqüidade se manifesta de forma mais expressiva. Mas, em todas as hipóteses, a atividade judicial contribui para a correta aplicação do direito aos casos concretos. É o que os romanos denominavam de atuação adjuvandi causa do juiz. Só assim é possível a concretização dos valores sociais que constituem o substractum dos preceitos normativos. Se a eqüidade só pode ser utilizada nos casos previstos em lei, como, então, compor a solução reparatória dos danos morais?

Realmente, o objeto da ciência jurídica é o Direito no sentido normativo, isto é, como regra ordenadora da convivência social. Como ciência de caráter ético-normativo, tem por objeto a atividade humana dirigida ao justo (bem devido a outrém). A norma jurídica não é dada pela natureza, mas resulta de um ato de construção da inteligência e da vontade humana. Logo, é obra da cultura. Mas, não é só. Referida construção apresenta-se aos membros da comunidade como um conjunto de normas diretivas, de regras do dever ser, de imperativos. A ciência do Direito pertence, assim, ao grupo das ciências normativas. Como a Moral, ela diz o que deve ser feito. O Direito não visa explicar a vida social, mas conduzi-la, a fim de que a meta do bem comum seja atingida.

Nesta ordem de considerações, a ciência do Direito é uma ciência ético-operativa. Como ciência operativa, participa das características da ciência prática.

Assim sendo, adquire significativa importância o papel do magistrado. Cabe-lhe participar do desenvolvimento do Direito. A norma jurídica é a tipificação 
axiológica de uma situação de fato a ser aplicável a comportamentos futuros. A sentença que dela decorre resulta da individualização do preceito, da conversão da norma genérica na norma concreta, mediante o processo do conhecimento prático da prudência judicial. Como ensina Roscoe Pound, o juiz prolonga a obra do legislador. A sentença possui essência ética, regulando mais de perto a situação convivencial. Contribui o juiz para a realização efetiva do ideal de justiça imanente aos esquemas normativos.

Tais noções merecem ser relembradas para afastar a alegação de que há excesso de poder na composição dos danos morais, quando estes ficam a critério do magistrado. Este poder é da própria natureza do ato de julgar. $\mathrm{O}$ juiz recebe, por delegação normativa, o poder de converter a norma genérica da lei na norma concreta da sentença. Se o legislador não traça diretrizes, cabe ao juiz procurar a solução justa, equacionando, prudentemente, os dados que devem compor a decisão. É o que vem ocorrendo na fixação das sanções correspondentes aos ilícitos que redundam em danos morais.

Não é a eqüidade em recurso extraordinário e, sim, a solução normal, correta e necessária de toda interpretação judicial. Não há jurisprudência sem atuação da eqüidade. Jus est ars boni et aequi, diziam romanos. O "direito de normas" deve ser complementado pela "jurisprudência da eqüidade" (as expressões são de Heinrich Henkel). É a eqüidade o núcleo permanente do Direito, como preleciona Giuseppe Maggiore. ${ }^{43}$

Portanto, avaliando a conduta lesiva, o grau de culpabilidade, os motivos, as circunstâncias e as conseqüências do evento lesivo e ponderando, ainda, a respeito das possibilidades do obrigado, o juiz compõe, com prudência, a norma individualizada a ser aplicada ao caso concreto. São esses os fatores que possibilitam a solução justa. É o que, em excelente tese, ensina o Professor Carlos Alberto Bittar, in verbis: "Inserem-se, nesse contexto (da reparação) fatores subjetivos e objetivos, relacionados às pessoas envolvidas que, na prática, acabam influindo no espírito do julgador, a saber, de um lado, a análise do grau de culpa do lesante e a eventual participação do lesado na produção do efeito danoso; e de outro, a situação patrimonial e pessoal das partes e a proporcionalidade do preceito obtido com $o$ ilícito" 44 Em suma: a mensuração das medidas reparatórias deve levar em

43. Idem, L'equità e il suo valore nel Diritto, Rev. Internazionale di Filosofia del Diritto, p. 25687, 1923.

44. Carlos Alberto Bittar, Responsabilidade Civil por Danos Morais, tese, p. 209-14. 
consideração a gravidade objetiva do evento lesivo, a intensidade do elemento subjetivo da culpabilidade, a personalidade do agente, os motivos, as circunstâncias e as conseqüências do dano. Tais critérios guardam certa analogia com os que o magistrado leva em consideração para a aplicação da lei penal. Mas, no caso dos danos morais, o objetivo da sanção é compensatório e punitivo, motivo pelo qual, além daqueles critérios, deve ser sopesado o referente à situação patrimonial das partes envolvidas. 